\title{
Production of probiotic Bulgarian yoghurts obtained from an ultrafiltered cow's milk
}

\author{
S. Kodinova ${ }^{1}$, M. Dushkova $^{1 \dagger}$, M. Miteva-Petrova² ${ }^{2}$ V. Yanakieva ${ }^{3}$, S. Petrov², Z. Denkova ${ }^{3}$
}

${ }^{1}$ Department of Process Engineering, Technical Faculty, University of Food Technologies, Plovdiv, Bulgaria

${ }^{2}$ Department of Organic Chemical Technologies, Technical Sciences Faculty, University "Prof. Asen Zlatarov", Burgas, Bulgaria

${ }^{3}$ Department of Microbiology, Technological Faculty, University of Food Technologies, Plovdiv, Bulgaria

Abstract

Ultrafiltration of skim cow's milk with a UF10-PAN membrane at volume reduction ratios (VRRs) of 2 and 3 was performed. The ultrafiltration retentates obtained were used for production of probiotic yoghurts with three different starters. A control sample was prepared using skim cow's milk. All yoghurts were analysed according to the following parameters: titratable acidity, dry matter, organoleptic characteristics, number of specific microorganisms (Lactobacillus bulgaricus and Streptococcus thermophilus) and the total count of viable lactic acid bacteria for $28 \mathrm{~d}$ of storage. The results showed that the increase in the VRR during ultrafiltration increased the titratable acidity, as well as the dry matter of all yoghurts. Ultrafiltration concentration led to an increase in the count of viable lactic acid bacteria in all yoghurts which improved their functional properties. The highest values of the total number of viable lactic acid bacteria were determined in yoghurts obtained with starter $1 C M$, followed by starters $M Z_{2}$ and ZD for both VRRs. Probiotic yoghurts with the highest organoleptic evaluation were obtained from ultrafiltration retentates at VRR $=2$ and starters $1 C M$ and $M Z_{2}$.

Keywords

Cow's milk • probiotic yoghurt $\cdot$ ultrafiltration

\section{Introduction}

Ultrafiltration is widely used in the dairy industry for concentration, purification and fractionation of milk components as it has the following advantages in comparison with the traditional separation methods: environmental friendliness (Kumar et al., 2013; Tamime, 2013), lower energy consumption (Baldasso et al., 2011), increased yield (Macedo et al., 2012; Ong et al., 2013) and improved quality (Reschke da Cunha et al., 2006; Domagala and Wszolek, 2008; Heino et al., 2010; Domagala et al., 2012) of the final product, reduction in the production costs (Mehaia, 2005) and completion of the process at room temperature to treat heat-sensitive products and keep their natural properties (in comparison with thermal evaporation, for example; Baldasso et al., 2011).

Many fermented milk products are produced by ultrafiltration. When ultrafiltration was used for Greek yoghurt, it was established that yoghurts produced by ultrafiltration contained more lactic acid bacteria than those produced by traditional technology without ultrafiltration (Tamime et al., 2005). Sodini et al. (2005) used whey protein concentrates, obtained by ultrafiltration, to increase the protein content and enhance the development of lactic acid bacteria in the probiotic yoghurts produced.

Ymer is a national Danish soured milk product with an increased protein content, which can be obtained by traditional technology or by using membrane processes (Fonden et al., 2006). The ultrafiltration method for obtaining Ymer includes the following processing operations: heat treatment of skim milk at $85^{\circ} \mathrm{C}$ for $15 \mathrm{~s}$, ultrafiltration at a volume reduction ratio (VRR) of 1.9 and a temperature of $50-55^{\circ} \mathrm{C}$, standardisation of the retentate by the addition of cream, reheating to $85^{\circ} \mathrm{C}$ for $5 \mathrm{~min}$, homogenising and cooling to $22^{\circ} \mathrm{C}$. The coagulation is performed by mesophilic starter culture at $20-22^{\circ} \mathrm{C}$ for $14-16 \mathrm{~h}$. The advantage of this technology is higher protein content, which leads to an increase in yield from $8 \%$ to $15 \%$.

Özer (2006) developed a technology with ultrafiltration for the traditional sweet strained Indian yoghurt Shrikhand: skim cow's milk was subjected to pasteurisation at $85-90^{\circ} \mathrm{C}$ for $10-20 \mathrm{~min}$; then, it was cooled at $21-22^{\circ} \mathrm{C}$ and coagulated with mesophilic lactic acid bacteria during 15-16 $\mathrm{h}$. The fermented milk was reheated to $60^{\circ} \mathrm{C}$ for $5 \mathrm{~min}$, cooled at $50^{\circ} \mathrm{C}$ and subjected to ultrafiltration to increase the dry matter to $16 \%$. The product

\footnotetext{
† Corresponding author: M. Dushkova

E-mail:maria_douchkova@yahoo.fr
} 
obtained had a better taste, texture, colour and appearance than that obtained by traditional technology.

Kumis is an ancient fermented milk drink, commonly consumed in Eastern Europe and Central Asia. Traditionally, it is made from mare's milk, and its healing and nutritional properties are well known but the quantity of mare's milk is limited and the price is quite high. Küçükçetin et al. (2003) investigated the possibility of using cow's milk for the production of Kumis: skim cow's milk was treated by ultrafiltration to obtain a proteinenriched concentrate. The casein and whey proteins in the ultrafiltration concentrate were separated by microfiltration, and the resulting retentates had a composition close to the mare's milk.

Labneh is a traditional fermented milk product, popular in different parts of the world, especially in the Balkans. It has a sour taste, milky white colour, smooth and creamy texture. In traditional Labneh technology, whole yoghurt is drained through filtering tissue to obtain dry matter from $22 \%$ to $26 \%$ (Otaibi and Demerdash, 2008). A comparative assessment of the chemical composition, rheological and organoleptic properties of Labneh obtained from cow's milk using traditional technology and using ultrafiltration retentate with or without added concentrated permeate was made (Shamsia and ElGhannam, 2012). The authors found that the addition of $1 \%$ concentrated permeate containing $84 \%$ lactose, $11 \%$ mineral substances, $5 \%$ water and $1 \%$ glucono delta-lactone (GDL) resulted in a significant reduction in coagulation time and an increase in dry matter. The most significant reduction in coagulation time was observed when using a GDL. Compared with Labneh, obtained by traditional technology, when ultrafiltration was used the product was characterised by a higher content of total and soluble proteins, fats, minerals, acidity and $\mathrm{pH}$. The addition of $1 \%$ concentrated permeate during the production of Labneh by ultrafiltration results in an improvement in taste, appearance and structure of the product.

Mehaia (2005) explored the possibility of the production of Labneh from goat's milk by traditional technology and by using ultrafiltration before and after coagulation with starter culture. The author found that Labneh, produced by membrane technology, had higher acidity, higher protein, fat, dry matter and lower $\mathrm{pH}$. Ultrafiltration before and after coagulation led to an increase in yield of about $14.5 \%$. The production time was significantly reduced by $75 \%$, as well as the amount of starter used before $(12.5 \%)$ and after $(62.5 \%)$ ultrafiltration.

The aim of this research was to investigate the possibilities for the production of probiotic Bulgarian yoghurts obtained by ultrafiltration of skim cow's milk with a UF10-PAN membrane and assessment of their physicochemical, microbiological and organoleptic characteristics.

\section{Materials and methods}

\section{Materials}

Milk

The skim cow's milk was delivered by BCC Handel Ltd., Elena, Bulgaria. The milk was analysed for the following parameters: dry matter content (International Standardisation Organisation [ISO], Geneva, Switzerland 6731:2010); total protein content (Bulgarian State Standard [BSS] EN ISO 8961-1:2014); fat content (ISO 2446:2008); mineral substances (BSS $6154: 1974)$. All these analyses were conducted with threefold repetition.

Starter cultures

Three probiotic starter cultures were used for the production of Bulgarian yoghurts: starter culture ZD consisting of a probiotic strain of Lactobacillus bulgaricus (National Bank for industrial microorganisms and cell cultures NBIMCC 3706) and Streptococcus thermophilus (3); starter culture $\mathrm{MZ}_{2}$ consisting of a probiotic strain of $L$. delbrueckii subsp. bulgaricus (NBIMCC 3708) and S. thermophilus $\left(\mathrm{TMZ}_{2} \mathrm{I}\right)$; starter culture $1 \mathrm{CM}$ consisting of a probiotic strain of $L$. delbrueckii subsp. bulgaricus (NBIMCC 3708) and S. thermophilus (T3).

The ratio of $L$. delbrueckii subsp. bulgaricus and $S$. thermophilus was $1: 2$ in all starter cultures. The starter cultures were kindly provided by Prof. Zapryana Denkova from the Department of Microbiology at University of Food Technologies, Plovdiv, Bulgaria.

Media for development and maintenance of lactic acid bacteria: Sterile skim milk with a titratable acidity of $16-18^{\circ} \mathrm{T}-$ dried skim milk was provided by Scharlau, Barcelona, Spain, reconstituted to $9 \%$ dry matter content, autoclaved for $15 \mathrm{~min}$ at $118^{\circ} \mathrm{C}$ and cooled for storage at room temperature. Liquid medium (LAPTg10) for the development of lactic acid bacteria was prepared as follows: peptone - $15.0 \mathrm{~kg} / \mathrm{m}^{3}$ (Fluka, Bucharest, Romania); tryptone $-10.0 \mathrm{~kg} / \mathrm{m}^{3}$ (Fisher Scientific, Difco Laboratories, Hampton, USA); yeast extract - $10.0 \mathrm{~kg} /$ $\mathrm{m}^{3}$ (Scharlau), glucose $-10.0 \mathrm{~kg} / \mathrm{m}^{3}$ (Sigma Aldrich, Merck, St. Louis, MO, USA); Tween $80-1.0 \mathrm{~kg} / \mathrm{m}^{3}$ (Sigma Aldrich). The $\mathrm{pH}$ of the liquid medium was 6.6-6.8 and the solid medium of LAPTg10 was $15.0 \mathrm{~kg} / \mathrm{m}^{3}$ agar (Sigma Aldrich).

\section{Methods}

Cultivation and storage of probiotic starter cultures for yoghurt The starter cultures used ( $\left.\mathrm{ZD}, \mathrm{MZ}_{2}, 1 \mathrm{CM}\right)$ were inoculated every $20 \mathrm{~d}$ in sterile skim milk with a titratable acidity of 16 $18^{\circ} \mathrm{T}$ and stored at $4-6^{\circ} \mathrm{C}$ or as stock cultures at $-20^{\circ} \mathrm{C}$. 


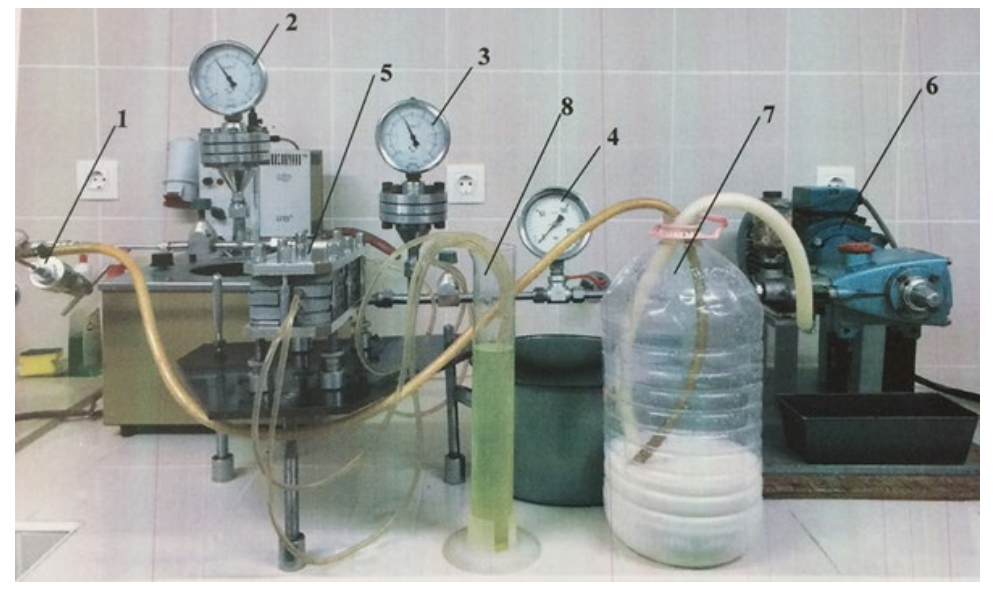

Figure 1. Scheme of laboratory equipment with a replaceable plate and frame membrane module. 1 : valve; 2,3 , 4: manometers; 5 : replaceable plate and frame membrane module; 6: pump; 7: tank for initial solution; 8: cylinder for permeate.

\section{Ultrafiltration experiments}

Ultrafiltration was carried out with polyacrylonitrile membrane UF10-PAN with $10 \mathrm{kDa}$ molecular weight cut-off. Membrane was prepared by the dry-wet phase inversion method of polymer solutions with a solvent of dimethyl sulphoxide (Sigma Aldrich). Then, it was heat-treated in an aqueous medium for $10 \mathrm{~min}$ at $60^{\circ} \mathrm{C}$. The membrane was prepared and kindly provided by the University Prof. Dr. Asen Zlatarov, Burgas, Bulgaria. Ultrafiltration experiments were carried out on laboratory equipment with a replaceable plate and frame membrane module (Figure 1). Ultrafiltration was undertaken at the following operating conditions: $\mathrm{VRR}=2$ and $\mathrm{VRR}=$ 3; working pressure, $0.5 \mathrm{MPa}$; temperature, $50^{\circ} \mathrm{C}$; volumetric flow rate, $330 \mathrm{dm}^{3} / \mathrm{h}$. The retentates obtained were then pasteurised at $65^{\circ} \mathrm{C}$ during $10-15 \mathrm{~min}$ and cooled at $42 \pm$ $1^{\circ} \mathrm{C}$. VRR was calculated by the following formula:

$$
\operatorname{VRR}=\frac{V_{0}}{V_{\mathrm{R}}}
$$

where $V_{0}$ is the volume of the feed solution and $V_{R}$ is the volume of retentate.

\section{Production of probiotic Bulgarian yoghurts}

The coagulation of cow's milk and retentates was performed under aseptic conditions in sterile plastic containers of $100 \mathrm{~cm}^{3}$ with $1.5 \%$ probiotic starter. The containers were placed in an incubator at $41-42^{\circ} \mathrm{C}$ for the coagulation of milk or retentates for $2.5-3 \mathrm{~h}$. After coagulation, the yoghurts were cooled and stored at $2-6^{\circ} \mathrm{C}$ for $28 \mathrm{~d}$.

\section{Analysis of milk, retentates and yoghurts}

The initial skim cow's milk and retentates obtained were analysed according to titratable and active acidity, total number of mesophilic anaerobic and facultative anaerobic microorganisms, as well as specific microorganisms, while the yoghurts were analysed according to dry matter, protein content, titratable acidity, specific microorganisms, number of viable lactic acid bacteria and organoleptic characteristics using the following methods.

\section{Physicochemical methods}

Dry matter was measured according to ISO 6731:2010; total protein content was investigated according to BSS EN ISO 8961-1:2014. The ability of lactic acid bacteria to form acids (titratable acidity, ${ }^{\circ} \mathrm{T}$ ) was measured by the Turner method according to BSS 1111:1980. $1^{\circ} \mathrm{T}$ was equal to $1 \mathrm{~cm}^{3}$ of $0.1 \mathrm{~N} \mathrm{NaOH}$ (Sigma Aldrich), necessary for neutralisation of an equivalent quantity of organic acid in $100 \mathrm{~cm}^{3}$ of culture medium. $10 \mathrm{~cm}^{3}$ from every sample was taken, and $20-\mathrm{cm}^{3}$ distilled water was added. The titration was performed with $0.1 \mathrm{~N} \mathrm{NaOH}$ using an indicator phenolphthalein until the appearance of light pink coloration, persistent for $1 \mathrm{~min}$. To measure the active acidity $(\mathrm{pH})$ a pen-type $\mathrm{pH}$ metre $(\mathrm{PH}$ 03 [I]; Hinotek, China) was used. All these analyses were conducted with threefold repetition.

\section{Microbiological methods}

The number of viable lactic acid bacteria was measured as appropriate serial dilutions of the yoghurts in saline solution $\mathrm{NaCl}$ (5 g/dm ${ }^{3}$; Sigma Aldrich) were prepared and the spread plate method was applied. $0.1 \mathrm{~cm}^{3}$ of the last three dilutions was used to inoculate in LAPTg10-agar for $3 \mathrm{~d}$ at $37^{\circ} \mathrm{C}$ until the appearance of countable single colonies. The total number of mesophilic anaerobic and facultative anaerobic microorganisms was measured according to BSS EN ISO 4833-1:2013. The count of Escherichia coli was established according to BSS EN ISO 16649-2:2014. The number of 
Table 1. Organoleptic analyses of indices and hedonic scale for evaluation of probiotic Bulgarian yoghurts

\begin{tabular}{|c|c|}
\hline \multicolumn{2}{|r|}{ Organoleptic indices for evaluation of probiotic Bulgarian yoghurts } \\
\hline Indices & Characteristics and norms \\
\hline 1. Colour & White with different shades of creamy hue depending on the raw materials used \\
\hline 2. Appearance of coagulum & Dense, smooth, lateral tear is allowed depending on the type of milk \\
\hline 3. Structure at cutting & $\begin{array}{c}\text { Smooth surface, with or without a grain-shaped structure, with or without a slight separation of the whey } \\
\text { depending on the raw materials used }\end{array}$ \\
\hline 4. Consistency at shattering & Uniform, homogeneous, cream-like, light-grained or grained structure depending on the raw material used \\
\hline 5. Taste and aroma & A pleasant, lactic acid. No side taste and odour is allowed \\
\hline \multicolumn{2}{|r|}{ Hedonic scale for evaluation of probiotic Bulgarian yoghurts } \\
\hline Evaluation & Points \\
\hline I dislike extremely & 1 \\
\hline I dislike & 2 \\
\hline I neither like nor dislike & 3 \\
\hline I like & 4 \\
\hline I like extremely & 5 \\
\hline
\end{tabular}

Staphylococcus aureus was identified according to BSS EN ISO 6888-1:2005+A $: 2005$. The concentration of Salmonella was defined according to BSS EN ISO 6579:2003. To measure yeasts and moulds, BSS EN ISO 6611:2006 was used. All these analyses were conducted with threefold repetition.

\section{Organoleptic analysis}

Organoleptic analysis was performed using a 5-point hedonic scale for evaluation, and the basic organoleptic indices are presented in Table 1. A nine-member experienced panel drawn from the Department of Microbiology at the University of Food Technologies, Plovdiv, Bulgaria, was used to evaluate the samples. The panellists rated the samples three times in a random order for colour, appearance of coagulum, structure at cutting, consistency at shattering, taste and aroma. Room temperature water and unsalted crackers were given to the panellists for mouth rinsing between samples to eliminate carry-over effects.

\section{Statistical method}

The least significant difference (LSD) method was used at the level of significance 0.05, using Microsoft Excel 2010, for comparison between the control and retentates VRR $=2$ and $\operatorname{VRR}=3$, as well as between the three starter cultures.

\section{Results}

The main components, titratable acidity and $\mathrm{pH}$ of the initial skim milk and ultrafiltration retentates at VRR $=2$ and VRR $=$ 3 are presented in Table 2. It can be seen that the increase in VRR led to an increase in the dry matter, protein, fat contents and mineral substances. The experimental results of the titratable acidity and $\mathrm{pH}$ showed that the lowest values of the titratable acidity were observed for the control followed by the ultrafiltration retentates at $\mathrm{VRR}=2$ and 3 . Titratable acidity increased from $23 \pm 0.36^{\circ} \mathrm{T}(\mathrm{VRR}=2)$ to $31 \pm 0.09^{\circ} \mathrm{T}(\mathrm{VRR}=$ 3 ) in comparison with the control $\left(16 \pm 0.18^{\circ} \mathrm{T}\right)$. Table 2 also shows that the $\mathrm{pH}$ decreased when using the ultrafiltration process.

The results of the total number of mesophilic aerobic and facultative anaerobic microorganisms, specific microorganisms (E. coli, S. aureus and Salmonella, moulds and yeasts in the initial skim milk and ultrafiltration retentates show that the increase in VRR led to an increase in the total number of mesophilic aerobic and facultative anaerobic microorganisms $(P<0.05)$. The lowest values were found for the control $\left(1.8 \times 10^{2} \pm 0.1 \times 10^{2} \mathrm{cfu} / \mathrm{cm}^{3}\right)$, followed by the ultrafiltration retentate at VRR $=2\left(2.5 \times 10^{2} \pm 0.1 \times 10^{2} \mathrm{cfu} / \mathrm{cm}^{3}\right)$ and VRR $=3\left(3.8 \times 10^{2} \pm 0.13 \times 10^{2} \mathrm{cfu} / \mathrm{cm}^{3}\right)$. The analysis for specific microorganisms in probiotic yoghurts obtained from the initial skim milk (control) and ultrafiltration retentates at VRRs of 2 and 3 showed that E. coli and S. aureus were less than $10 \mathrm{cfu} / \mathrm{g}$, and Salmonella was not found in $25 \mathrm{~g}$ of the product. The count of moulds and yeasts was below $10 \mathrm{cfu} / \mathrm{g}$ in all tested probiotic yoghurts.

The results of the dry matter and protein content of the probiotic yoghurts obtained are presented in Table 3. The dry matter content of the controls was as follows: for ZD, $(8.80$ $\pm 0.14 \%)$; for $\mathrm{MZ}_{2},(8.87 \pm 0.16 \%)$; for $1 \mathrm{CM},(8.90 \pm 0.11 \%)$. The dry matter of the yoghurts obtained from ultrafiltration retentate at VRR = 2 was as follows: for ZD, $(12.20 \pm 0.10 \%)$; for $\mathrm{MZ}_{2}$, $(12.25 \pm 0.12 \%)$; for $1 \mathrm{CM},(12.40 \pm 0.10 \%)$. The highest values were defined at $\mathrm{VRR}=3$ : for $\mathrm{ZD},(15.30 \pm$ $0.16 \%)$; for $\mathrm{MZ}_{2}$, (15.35 $\left.\pm 0.12 \%\right)$; for $1 \mathrm{CM}$, (15.38 $\left.\pm 0.13 \%\right)$. The data show that the highest values of the protein content 
Table 2. Main components and chemical properties of initial skim milk and ultrafiltration retentates at VRR $=2$ and VRR $=3$

\begin{tabular}{|c|c|c|c|c|}
\hline \multirow[t]{2}{*}{ Indices } & \multicolumn{3}{|c|}{ Sample } & \multirow{2}{*}{$\begin{array}{c}\text { Average values } \\
\pm \text { s.d. }\end{array}$} \\
\hline & 1 & 2 & 3 & \\
\hline \multicolumn{5}{|l|}{ Membrane UF10-PAN } \\
\hline \multicolumn{5}{|l|}{ Skim milk } \\
\hline Dry matter content, \% & 8.90 & 8.85 & 8.87 & $8.87 \pm 0.03^{\mathrm{a}}$ \\
\hline Total protein content, \% & 3.21 & 3.26 & 3.27 & $3.25 \pm 0.03^{a}$ \\
\hline Fat content, \% & 0.1 & 0.1 & 0.05 & $0.08 \pm 0.04^{\mathrm{a}}$ \\
\hline Mineral substances, $\%$ & 0.71 & 0.72 & 0.72 & $0.72 \pm 0.01^{a}$ \\
\hline Titratable acidity, ${ }^{\circ} \mathrm{T}$ & 15.82 & 16.0 & 16.18 & $16.0 \pm 0.18^{a}$ \\
\hline $\mathrm{pH}$ & 6.75 & 6.76 & 6.74 & $6.75 \pm 0.01^{\mathrm{a}}$ \\
\hline \multicolumn{5}{|l|}{ VRR = 2} \\
\hline Dry matter content, \% & 12.23 & 12.24 & 12.25 & $12.24 \pm 0.01^{b}$ \\
\hline Total protein content, \% & 5.59 & 5.59 & 5.74 & $5.64 \pm 0.09^{b}$ \\
\hline Fat content, \% & 0.2 & 0.2 & 0.1 & $0.17 \pm 0.06^{\mathrm{a}}$ \\
\hline Mineral substances, $\%$ & 0.96 & 0.96 & 0.97 & $0.96 \pm 0.01^{b}$ \\
\hline Titratable acidity, ${ }^{\circ} \mathrm{T}$ & 22.64 & 23 & 23.36 & $23 \pm 0.36^{b}$ \\
\hline $\mathrm{pH}$ & 6.60 & 6.65 & 6.63 & $6.62 \pm 0.02^{\mathrm{b}}$ \\
\hline \multicolumn{5}{|l|}{ VRR $=3$} \\
\hline Dry matter content, \% & 15.33 & 15.37 & 15.35 & $15.35 \pm 0.02^{c}$ \\
\hline Total protein content, \% & 6.93 & 7.37 & 7.39 & $7.23 \pm 0.26^{c}$ \\
\hline Fat content, \% & 0.3 & 0.3 & 0.15 & $0.25 \pm 0.09^{a}$ \\
\hline Mineral substances, $\%$ & 1.24 & 1.24 & 1.25 & $1.24 \pm 0.01^{\mathrm{c}}$ \\
\hline Titratable acidity, ${ }^{\circ} \mathrm{T}$ & 30.91 & 31 & 31.09 & $31 \pm 0.09^{c}$ \\
\hline $\mathrm{pH}$ & 6.50 & 6.52 & 6.51 & $6.51 \pm 0.01^{\mathrm{c}}$ \\
\hline
\end{tabular}

${ }^{\mathrm{a}-\mathrm{c}}$ To compare the composition of skim milk and retentates at $\mathrm{VRR}=2$ and $\mathrm{VRR}=3$.

VRR, volume reduction ratio.

Table 3. Dry matter and protein content of probiotic Bulgarian yoghurts from initial skim milk (control) and ultrafiltration retentates at VRR $=2$ and $\mathrm{VRR}=3$

\begin{tabular}{|c|c|c|c|c|c|c|c|c|}
\hline \multirow{2}{*}{$\begin{array}{l}\text { Probiotic } \\
\text { yoghurts } \\
\text { with different } \\
\text { starters }\end{array}$} & \multicolumn{3}{|c|}{ Dry matter, \% } & \multirow{2}{*}{$\begin{array}{c}\text { Average } \\
\text { values } \\
\pm \text { s.d. }\end{array}$} & \multicolumn{3}{|c|}{ Protein content, \% } & \multirow{2}{*}{$\begin{array}{c}\text { Average values } \\
\pm \text { s.d. }\end{array}$} \\
\hline & 1 & 2 & 3 & & 1 & 2 & 3 & \\
\hline ZD (control) & 8.66 & 8.80 & 8.94 & $8.80 \pm 0.14^{a}$ & 3.22 & 3.24 & 3.28 & $3.25 \pm 0.03^{a}$ \\
\hline ZD (VRR = 2) & 12.10 & 12.20 & 12.30 & $12.20 \pm 0.10^{b}$ & 5.60 & 5.70 & 5.63 & $5.64 \pm 0.05^{b}$ \\
\hline ZD (VRR = 3) & 15.14 & 15.30 & 15.46 & $15.30 \pm 0.16^{c}$ & 7.28 & 7.20 & 7.22 & $7.23 \pm 0.04^{c}$ \\
\hline $\mathrm{MZ}_{2}$ (control) & 8.71 & 8.87 & 9.03 & $8.87 \pm 0.16^{a}$ & 3.26 & 3.30 & 3.31 & $3.29 \pm 0.03^{a}$ \\
\hline$M Z_{2}(\mathrm{VRR}=2)$ & 12.13 & 12.25 & 12.37 & $12.25 \pm 0.12^{b}$ & 5.70 & 5.74 & 5.62 & $5.69 \pm 0.06^{b}$ \\
\hline$M Z_{2}(\mathrm{VRR}=3)$ & 15.23 & 15.35 & 15.47 & $15.35 \pm 0.12^{c}$ & 7.25 & 7.31 & 7.35 & $7.30 \pm 0.05^{c}$ \\
\hline $1 \mathrm{CM}$ (control) & 8.79 & 8.90 & 9.01 & $8.90 \pm 0.11^{a}$ & 3.32 & 3.28 & 3.32 & $3.31 \pm 0.02^{\mathrm{a}}$ \\
\hline $1 \mathrm{CM}(\mathrm{VRR}=2)$ & 12.30 & 12.40 & 12.50 & $12.40 \pm 0.10^{\mathrm{b}}$ & 5.81 & 5.69 & 5.66 & $5.72 \pm 0.08^{b}$ \\
\hline $1 \mathrm{CM}(\mathrm{VRR}=3)$ & 15.25 & 15.38 & 15.51 & $15.38 \pm 0.13^{c}$ & 7.30 & 7.33 & 7.40 & $7.34 \pm 0.05^{c}$ \\
\hline
\end{tabular}

${ }^{\mathrm{a}-\mathrm{c} T o}$ compare the dry matter and protein content of the obtained yoghurts with three probiotic starters $\left(\mathrm{ZD}, \mathrm{MZ} \mathrm{Z}_{2}, 1 \mathrm{CM}\right)$, and they indicate that mean values in the columns are significantly different $(P<0.05)$.

VRR, volume reduction ratio. 

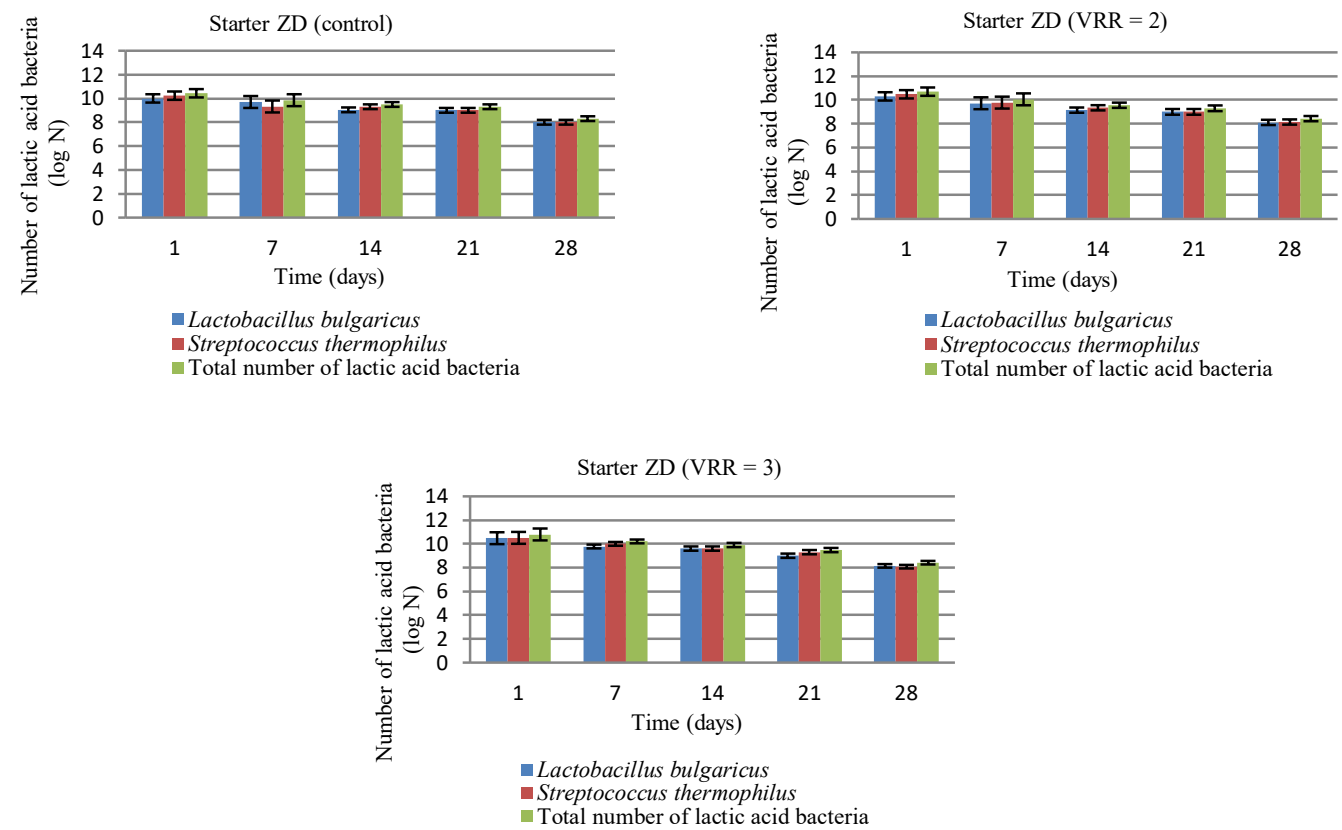

Figure 2. Microbiological status of probiotic Bulgarian yoghurts (control and ultrafiltration retentates at VRR $=2$ and VRR $=3$ ) with starter ZD. VRR, volume reduction ratio.

were defined for yoghurts obtained from retentate at $\mathrm{VRR}=$ 3: for ZD, $(7.23 \pm 0.04 \%)$; for $\mathrm{MZ}_{2}$, $(7.30 \pm 0.05 \%)$; for $1 \mathrm{CM}$, $(7.34 \pm 0.05 \%)$.

The changes in the number of Lactobacillus bulgaricus, $S$. thermophilus, as well as the total number of viable lactic acid bacteria for 28 -day storage at a temperature of $2-6^{\circ} \mathrm{C}$ for all probiotic yoghurts were investigated. The results of experimental investigations are shown in Figures 2-4. The comparison of $L$. bulgaricus for each of the storage stages for the three types of yoghurt (control and ultrafiltration retentates at VRR $=2$ and VRR $=3$ ) with starter ZD (Figure 2 ) showed that on the first day of the storage period the number of rod-shaped forms was higher $(P<0.05)$ at VRR $=2\left(2 \times 10^{10} \pm 0.35 \times 10^{10} \mathrm{cfu} / \mathrm{g}\right)$ and VRR $=3\left(3 \times 10^{10} \pm\right.$ $\left.0.5 \times 10^{10} \mathrm{cfu} / \mathrm{g}\right)$ in comparison with the control $-1 \times 10^{10} \pm$ $0.35 \times 10^{10} \mathrm{cfu} / \mathrm{g}$. Similar results were obtained for coccusshaped forms $-3 \times 10^{10} \pm 0.35 \times 10^{10} \mathrm{cfu} / \mathrm{g}$ at VRR $=2$ and $3.2 \times 10^{10} \pm 0.5 \times 10^{10} \mathrm{cfu} / \mathrm{g}$ at VRR $=3$ in comparison with $1.7 \times 10^{10} \pm 0.35 \times 10^{10} \mathrm{cfu} / \mathrm{g}$ in the control. The total count of viable lactic acid bacteria was highest in yoghurt obtained from ultrafiltration retentate at VRR $=3\left(6.2 \times 10^{10} \pm 0.5 \times\right.$ $\left.10^{10} \mathrm{cfu} / \mathrm{g}\right)$, followed by ultrafiltration retentate at VRR $=2(5$ $\left.\times 10^{10} \pm 0.35 \times 10^{10} \mathrm{cfu} / \mathrm{g}\right)$ and control $\left(2.7 \times 10^{10} \pm 0.35 \times 10^{10}\right.$ $\mathrm{cfu} / \mathrm{g})$. The concentration of viable cells of the probiotic strain L. bulgaricus, $S$. thermophilus and the total number of viable lactic acid bacteria remained high during the whole storage period, above $-2 \times 10^{8} \mathrm{cfu} / \mathrm{g}$, as the strongest reduction was observed on the 28th day of the storage period.

The change in L. bulgaricus and $S$. thermophilus, as well as the total number of lactic acid bacteria of probiotic yoghurts (control and ultrafiltration retentates at VRR $=2$ and VRR = 3) with starter $M Z_{2}$, is presented in Figure 3 . The results indicate that on the first day of the storage period the number of rod-shaped forms was higher $(P<0.05)$ at VRR $=2(2.8 \mathrm{x}$ $\left.10^{10} \pm 0.34 \times 10^{10} \mathrm{cfu} / \mathrm{g}\right)$ and VRR $=3\left(3.8 \times 10^{10} \pm 0.20 \times 10^{10}\right.$ $\mathrm{cfu} / \mathrm{g}$ ) in comparison with the control $-2 \times 10^{10} \pm 0.32 \times 10^{10}$ $\mathrm{cfu} / \mathrm{g}$. A similar trend was observed for the coccus-shaped forms: $1.1 \times 10^{10} \pm 0.32 \times 10^{10} \mathrm{cfu} / \mathrm{g}$ in control in comparison with $1.5 \times 10^{10} \pm 0.34 \times 10^{10} \mathrm{cfu} / \mathrm{g}$ at VRR $=2$ and $4 \times 10^{10} \pm$ $0.20 \times 10^{10} \mathrm{cfu} / \mathrm{g}$ at VRR $=3$. The amount of viable cells was kept high during all storage periods, and on the 28th day it was above $8 \times 10^{8} \mathrm{cfu} / \mathrm{g}$.

The dynamics of the change in L. bulgaricus, S. thermophilus and the total number of lactic acid bacteria of probiotic yoghurts (control and ultrafiltration retentates at $\mathrm{VRR}=2$ and VRR = 3) with starter $1 \mathrm{CM}$ is presented in Figure 4 . The data show that their concentration is greatest in yoghurt from ultrafiltration retentate at $\mathrm{VRR}=3$, followed by the yoghurt from ultrafiltration retentate at $\mathrm{VRR}=2$ and the control. $A$ reduction in the amount of viable lactic acid bacteria was observed during the studied storage period, and the biggest decrease was observed from the 21 st to the 28th day. 

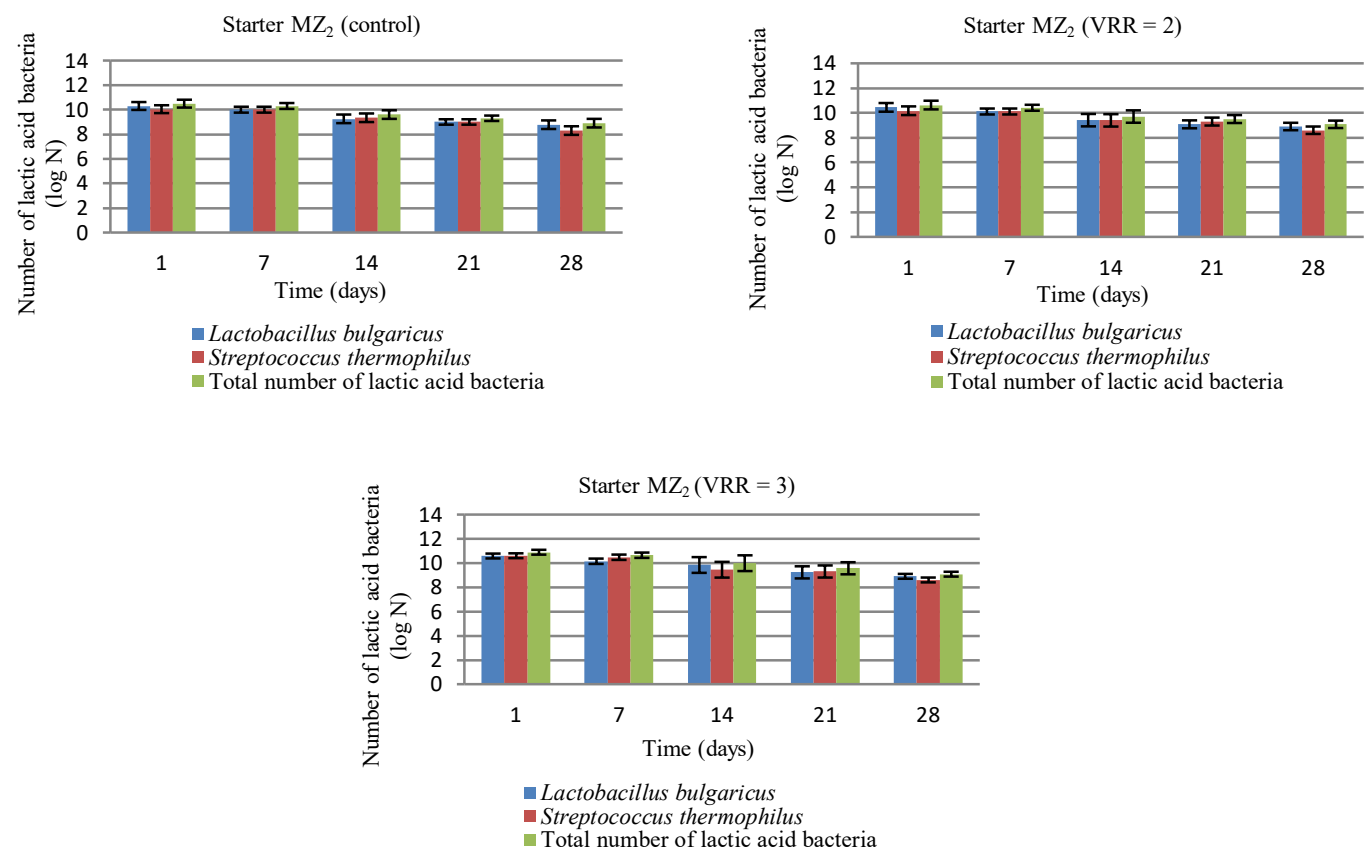

Figure 3. Microbiological status of probiotic Bulgarian yoghurts (control and ultrafiltration retentates at $V R R=2$ and $V R R=3$ ) with starter $M Z_{2}$. VRR, volume reduction ratio.
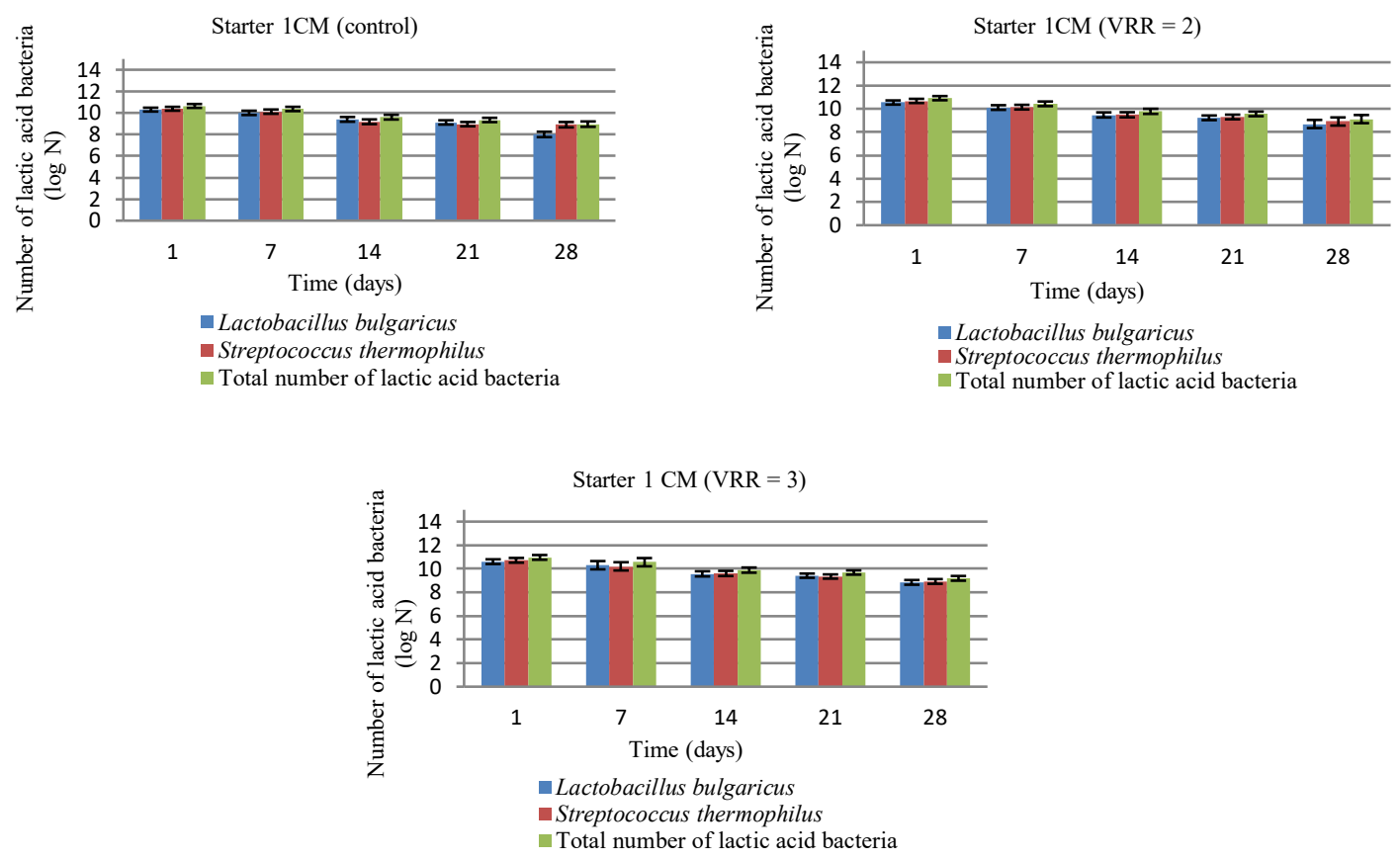

Figure 4. Microbiological status of probiotic Bulgarian yoghurts (control and ultrafiltration retentates at VRR $=2$ and VRR $=3$ ) with starter $1 \mathrm{CM}$. VRR, volume reduction ratio. 

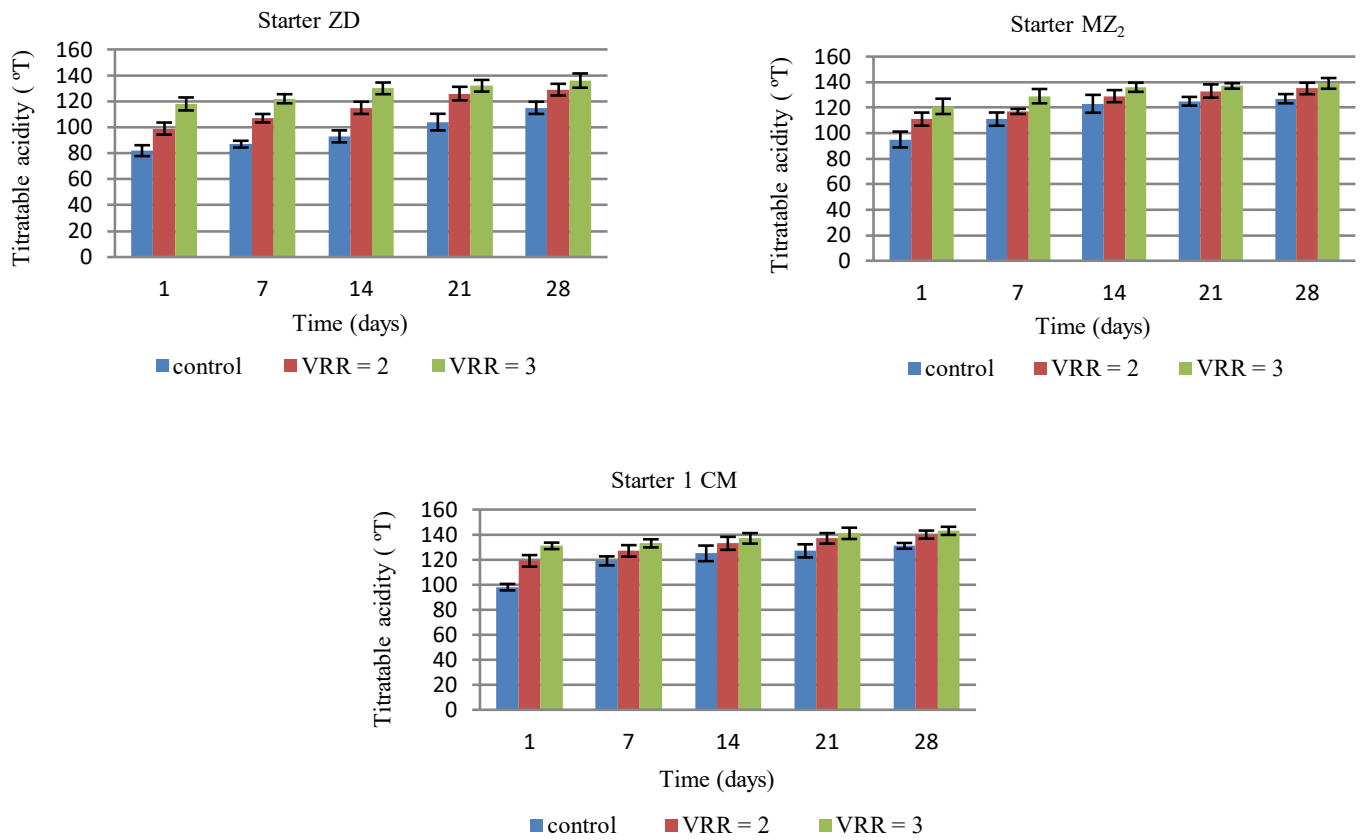

Figure 5. Kinetics of titratable acidity of probiotic Bulgarian yoghurts (control and ultrafiltration retentates at VRR $=2$ and VRR $=3$ ) with starters $\mathrm{ZD}, \mathrm{MZ}_{2}$ and $1 \mathrm{CM}$. VRR, volume reduction ratio.

The titratable acidity of the yoghurts (control and ultrafiltration retentates at VRR $=2$ and VRR $=3$ ) with three types of probiotic starters was determined (Figure 5 ). The results show that the titratable acidity of all yoghurts increased $(P$ $<0.05)$ with VRR of the milk used in manufacture and with storage time.

The results of organoleptic evaluation of the probiotic yoghurts are presented in Table 4 . The data show that the yoghurts from retentate at $\mathrm{VRR}=2$ with all starter cultures had the highest number of points. Yoghurts, which had the higher total number of points, were these with starters $\mathrm{MZ}_{2}$ and $1 \mathrm{CM}$ in comparison with starter ZD.

\section{Discussion}

Table 2 shows that the increase in VRR led to an increase in titratable acidity $(P<0.05)$. This could be explained by the higher protein content obtained with ultrafiltration. MorenoMontoro et al. (2015) reported that the increased protein content leads to a higher buffering capacity which results in greater titratable acidity. The authors established significantly higher values of titratable acidity in ultrafiltered retentates from goat's milk in comparison with skim goat's milk and enhanced nutritional value because of the increase in dry matter, protein, fat contents and mineral substances. The increase in VRR resulted in a decrease in the active acidity $(\mathrm{pH})$ of the investigated samples $(P<0.05)$.

Low levels of ultrafiltration concentration (VRR $=2$ and VRR = 3 ) were used for the production of probiotic yoghurts because at higher levels the dry matter and protein content increase the density and the viscosity of the milk, which slows down the acid coagulation (Meletharayil et al., 2015; Arango et al., 2018).

The increase in the total number of mesophilic aerobic and facultative anaerobic microorganisms in retentates could be explained by the decrease in the volume of the initial skim milk and higher concentration of microorganisms during ultrafiltration. It can be seen that in microbiological analysis, the initial skim milk and ultrafiltration retentates at VRR $=2$ and 3 were in agreement with the admissible hygienic and epidemiological assessment norms according to the instruction from 31 July 2004 for the Maximum Allowable Quantities of Pollutants in Foods (Official Journal of Bulgarian Government, issue 88/8, 2004).

The statistical analysis of the data in Table 3 shows that there was no significant difference $(P>0.05)$ between the dry matter content of the yoghurts obtained with the three probiotic starters $\left(\mathrm{ZD}, \mathrm{MZ}_{2}, 1 \mathrm{CM}\right)$ in all tested combinations. It can also be seen that the increase in VRR led to an increase in the dry matter content of the samples which could 
Table 4. Organoleptic characteristics of probiotic Bulgarian yoghurts from skim milk (control and retentates at VRR $=2$ and VRR $=3$ ) with different starters

\begin{tabular}{|c|c|c|c|}
\hline Indices & \multicolumn{3}{|c|}{ Type of probiotic yoghurt } \\
\hline \multicolumn{4}{|c|}{ Starter ZD } \\
\hline & Control & VRR = 2 & VRR $=3$ \\
\hline Appearance of coagulum & $\begin{array}{l}\text { Loose, smooth coagulum with slight } \\
\text { lateral tearing during inclination of the } \\
\text { package }-4 \text { points }\end{array}$ & Dense, smooth coagulum - 4 points & Dense, grainy coagulum - 4 points \\
\hline Consistency at shattering & Homogenous -4 points & Homogenous -5 points & Homogenous -4 points \\
\hline Colour & White with creamy hue -5 points & White with creamy hue -5 points & White with creamy hue -5 points \\
\hline Structure at cutting & $\begin{array}{l}\text { Smooth surface, with abundant sepa- } \\
\text { ration of whey }-3 \text { points }\end{array}$ & $\begin{array}{l}\text { Smooth surface, with slight separation } \\
\text { of whey }-4 \text { points }\end{array}$ & $\begin{array}{c}\text { Smooth surface, with slight separation } \\
\text { of whey }-4 \text { points }\end{array}$ \\
\hline Taste and aroma & Slight cream-like taste -2 points & Slight cream-like taste -4 points & Slight cream-like taste -3 points \\
\hline Total points & 18 points & 22 points & 20 points \\
\hline \multicolumn{4}{|c|}{ Starter $\mathbf{M} \mathbf{Z}_{2}$} \\
\hline & Control & VRR = 2 & VRR $=3$ \\
\hline Appearance of coagulum & $\begin{array}{l}\text { Loose, smooth coagulum with slight } \\
\text { lateral tearing during inclination of the } \\
\text { package }-4 \text { points }\end{array}$ & Dense, smooth coagulum -5 points & Dense coagulum -3 points \\
\hline Consistency at shattering & Homogenous -5 points & Homogenous -5 points & Homogenous -4 points \\
\hline Colour & White with creamy hue -5 points & White with creamy hue -5 points & White with creamy hue -5 points \\
\hline Structure at cutting & $\begin{array}{l}\text { Smooth surface, with abundant sepa- } \\
\text { ration of whey }-3 \text { points }\end{array}$ & $\begin{array}{l}\text { Smooth surface, with slight separation } \\
\text { of whey }-4 \text { points }\end{array}$ & $\begin{array}{c}\text { Smooth surface, with slight separation } \\
\text { of whey }-4 \text { points }\end{array}$ \\
\hline Taste and aroma & Slight cream-like taste -5 points & Pleasant cream-like taste -4 points & Strong cream-like taste -3 points \\
\hline Total points & 22 points & 23 points & 19 points \\
\hline \multicolumn{4}{|c|}{ Starter $1 \mathrm{CM}$} \\
\hline & Control & VRR = 2 & VRR = 3 \\
\hline Appearance of coagulum & $\begin{array}{l}\text { Loose, smooth coagulum with slight } \\
\text { lateral tearing during inclination of the } \\
\text { package }-3 \text { points }\end{array}$ & Dense, smooth coagulum -4 points & Dense, grainy coagulum - 4 points \\
\hline Consistency at shattering & Homogenous -4 points & Homogenous -5 points & Homogenous -3 points \\
\hline Colour & White with creamy hue -5 points & White with creamy hue -5 points & White with creamy hue -5 points \\
\hline Structure at cutting & $\begin{array}{l}\text { Smooth surface, with abundant sepa- } \\
\text { ration of whey }-4 \text { points }\end{array}$ & $\begin{array}{l}\text { Smooth surface, with slight separation } \\
\text { of whey }-5 \text { points }\end{array}$ & $\begin{array}{c}\text { Smooth surface, with slight separation } \\
\text { of whey }-5 \text { points }\end{array}$ \\
\hline Taste and aroma & Slight cream-like taste -4 points & Pleasant cream-like taste -4 points & $\begin{array}{l}\text { Strong cream-like } \\
\text { taste }-3 \text { points }\end{array}$ \\
\hline Total points & 20 points & 23 points & 20 points \\
\hline
\end{tabular}

VRR, volume reduction ratio.

be explained by the volume reduction during ultrafiltration concentration.

There was an increase in concentration due to an increase in the total number of lactic acid bacteria (Figure 2). Similar results were reported by Damianova et al. (2009) who demonstrated that the addition of plant proteins stimulated the development and viability of lactic acid bacteria and contributed to maintaining their higher amounts in the final lactic acid product. Marafon et al. (2011) found that the addition of whey protein concentrate and sodium caseinate resulted in an increase in the number of viable cells of $L$. bulgaricus, S. thermophilus and the probiotic strain of Bifidobacterium animalis in the yoghurts obtained.

Figure 3 shows that the lowest values of the total number of lactic acid bacteria were observed in the controls, followed by the ultrafiltration retentates at $\mathrm{VRR}=2$ and $\mathrm{VRR}=3$. This could be explained by the different dry matter content in the samples investigated. Mahdian and Tehrani (2007) reported that increased dry matter content keeps higher concentrations of $L$. bulgaricus and S. thermophilus in the yoghurt obtained. 
There was research on the change in viable probiotic bacteria in the production of stirred-type yoghurt from goat's milk (Martin-Diana et al., 2003). The authors found that the addition of $3 \%$ whey protein concentrate resulted in an increase in the amount of S. thermophilus ST-20Y, L. acidophilus LA-5 and Bifidobacterium BB-12 - from $6.4 \mathrm{log}$ units to $8.7 \log$ units due to the increased protein content. Figure 3 also shows that a reduction was observed during the storage period and the biggest decrease was from the 21st to the 2th day. Similar results were also obtained from the experimental work of Oliveira et al. (2002) on the 28th day of storage in lactic acid beverages.

Comparing the total number of viable lactic acid bacteria of the three starter cultures used, it could be seen that the highest values were observed in the yoghurt with starter $1 \mathrm{CM}$ $(P<0.05)$, followed by the starter $\mathrm{MZ}_{2}(P<0.05)$ and starter ZD $(P<0.05)$. This dependence concerns both controls and yoghurts derived from ultrafiltration retentates at $\mathrm{VRR}=2$ and $\operatorname{VRR}=3$.

Figure 5 shows that the lowest values of titratable acidity were obtained in the controls, followed by yoghurts from ultrafiltration retentates at $\mathrm{VRR}=2$ and $\mathrm{VRR}=3$. This was probably due to the higher protein content in ultrafiltered retentates, which was favourable for the growth of lactic acid bacteria. This led to a higher concentration of lactic acid. The strongest increase in titratable acidity was observed in the period from 1 to $14 \mathrm{~d}$, after which it remained practically unchanged. This could be explained by the inhibition in the growth of lactic acid bacteria from accumulated lactic acid during the storage period (Kondratenko and Simov, 2003). Figure 5 shows that yoghurt with the highest acidity was obtained with starter $1 \mathrm{CM}$, followed by starters $\mathrm{MZ}_{2}$ and starters ZD. This was probably due to the higher content of $S$. thermophilus in the yoghurts examined. The $\mathrm{pH}$ of the yoghurts was not measured as it is likely to have decreased with VRR owing to the increase in titratable acidity.

\section{Conclusion}

The results show that the increase in VRR led to an increase in the titratable acidity of initial milk, ultrafiltered retentates and yoghurts obtained. The level of ultrafiltration concentration led to an increase in the count of viable lactic acid bacteria in all yoghurts which improved their functional properties. The highest values of the total number of viable lactic acid bacteria were determined in Bulgarian yoghurts obtained with starter $1 \mathrm{CM}$, followed by starters $\mathrm{MZ}_{2}$ and $\mathrm{ZD}$. Probiotic yoghurts with the highest organoleptic evaluation were obtained from ultrafiltration retentates at volume reduction ratio $\mathrm{VRR}=2$ and starters $1 \mathrm{CM}$ and $\mathrm{MZ}_{2}$.

\section{References}

Arango, O., Trujillo, A.J. and Castillo, M. 2018. Monitoring the effect of inulin, protein, and calcium on milk coagulation phases using a fibre optic sensor. International Dairy Journal 81: 80-86.

Baldasso, C., Barros, T.C. and Tessaro, I.C. 2011. Concentration of whey proteins by ultrafiltration. Desalination 278: 381-386.

Bulgarian State Standard BSS 1111:1980. Milk and milk products determination of acidity.

Bulgarian State Standard BSS 6154:1974. Milk and milk products. Methods for determination of ash content.

Bulgarian State Standard BSS EN ISO 4833-1:2013. Microbiology of the food chain - horizontal method for the enumeration of microorganisms - part 1: Colony count at $30^{\circ} \mathrm{C}$ by the pour plate technique.

Bulgarian State Standard BSS EN ISO 6579: 2003. Microbiology of food and animal feeding stuffs - horizontal method for the detection of Salmonella spp (ISO 6579:2002).

Bulgarian State Standard BSS EN ISO 6888-1:2005 + A : 2005. Microbiology of food and animal feeding stuffs - horizontal method for the enumeration of coagulase-positive staphylococci (Staphylococcus aureus and other species) - part 1: technique using Baird-Parker agar medium - amendment 1: inclusion of precision data (ISO 6888-1:1999/Amd 1:2003).

Bulgarian State Standard BSS EN ISO 16649-2:2014. Microbiology of food and animal feeding stuffs - horizontal method for the enumeration of beta- glucuronidase-positive Escherichia coli - part 2: Colony count technique at $44^{\circ} \mathrm{C}$ using 5-bromo-4-chloro-3-indolul beta-D-glucuronide.

Bulgarian State Standard BSS ISO 6611:2006. Milk and milk products enumeration of colony-forming units of yeasts and/or moulds colony-count technique at $25^{\circ} \mathrm{C}$.

Damianova, S., Vasileva, N., Todorova, S., Stefanova, R. and Ganeva, E. 2009. Obtaining of functional food products. I. Yogurt with oat meal. Proceedings of Rouse University, Bulgaria, Volume 48, pages 169-174. (In Bulgarian).

Domagala, J. and Wszolek, M. 2008. Effect of concentration method and starter culture type on the texture and susceptibility to syneresis of yoghurt and bio-yoghurts made of goat's milk. ZywnoscNauka, Technologia, Jakosc 15: 118-128.

Domagala, J., Wszolek, M. and Dudzinska, A. 2012. The influence of the fortification method and starter culture type on the texture and microstructure of probiotic yoghurts prepared from goat's milk. Milchwissenschaft 67: 172-176.

Fonden, R., Leporanta, K. and Svensson, U. 2006. Nordic/Scandinavian fermented milk products. In: "Fermented Milks", 1st Edition (ed. A.Y. Tamime), Blackwell Science Ltd, Oxford, UK, pages 156-173.

Heino, A., Uusi-Rauva, J. and Outinen, M. 2010. Pre-treatment methods of Edam cheese milk. Effect on cheese yield and quality. Journal of Food Science and Technology 43: 640-646. 
ISO 2446:2008. Milk - determination of fat content.

ISO 6731:2010 (IDF 21:2010). Milk, cream and evaporated milk - determination of total solids content (Reference method).

ISO 8968-1:2014 (IDF 20-1:2014). Milk and milk products - determination of nitrogen content - part 1: Kjeldahl principle and crude protein calculation.

Kondratenko, M.S. and Simov, J.I. 2003. "Bulgarian yoghurt". Association of Dairy Processors in Bulgaria, Sofia, 262. (In Bulgarian).

Küçükçetin, A., Yagin, H., Hinrichs, J. and Kulozik, U. 2003. Adaptation of bovine milk towards mare's milk composition by means of membrane technology for koumiss manufacture. International Dairy Journal 13: 945-951.

Kumar, P., Sharma, N., Ranjan, R., Kumar, S., Bhat, Z. and Jeong, D. 2013. Perspective of membrane technology in dairy industry: a review. Asian-Australasian Journal of Animal Sciences 26: 13471358.

Macedo, A., Pinho, M. and Duarte, E. 2012. Application of ultrafiltration for valorization of ovine cheese whey. Procedia Engineering 44: 1949-1950.

Mahdian, E. and Tehrani, M. 2007. Evaluation of the effect of milk total solids on the relationship between growth and activity of starter cultures and quality of concentrated yoghurt. American-Eurasian Journal of Agricultural and Environmental Sciences 2: 587-592.

Marafon, A.P., Sumi, A., Alcantara, M.R., Tamime, A.Y. and Oliveira, M.N. 2011. Optimization of the rheological properties of probiotic yoghurts supplemented with milk proteins. LWT - Food Science and Technology 44: 511-519.

Martìn-Diana, A.B., Janer, C., Peláez, I. and Requena, T. 2003. Development of a fermented goat's milk containing probiotic bacteria. International Dairy Journal 13: 827-833.

Mehaia, M.A. 2005. Manufacture of fresh Labneh from goat's milk using ultrafiltration process. Journal of Food Technology 3: 24-29.

Meletharayil, G.H., Patel, H.A. and Huppertz, T. 2015. Rheological properties and microstructure of high protein acid gels prepared from reconstituted milk protein concentrate powders of different protein contents. International Dairy Journal 47: 64-71.

Moreno-Montoro, M., Olalla, M., Giménez-Martínez, R., BergillosMeca, T., Ruiz-López, M., Cabrera-Vique, C., Artacho, R. and Miguel Navarro-Alarcón, M. 2015. Ultrafiltration of skim goat's milk increases its nutritional value by concentrating nonfat solids such as proteins, Ca, P, Mg, and Zn. Journal of Dairy Science $\mathbf{9 8}$ : 7628-7634.

Oliveira, M.N., Sodini, I., Remeuf, F., Tissier, J.P. and Corrieu, G. 2002. Manufacture of fermented lactic beverages containing probiotic cultures. Journal of Food Science 67: 2336-2341.

Ong, L., Dagastine, R., Kentish, S. and Gras, S. 2013. Microstructure and composition of full fat Cheddar cheese made with ultrafiltered milk retentate. Foods 2: 310-331.

Otaibi, M.A. and El Demerdash, H. 2008. Improvement of the quality and shelf life of concentrated yoghurt (labneh) by the addition of some essential oils. African Journal of Microbiology Research 2: 156-161.
Özer, B.H. 2006. Production of concentrated products. In: "Fermented Milks", 1st Edition (ed. A.Y. Tamime), Blackwell Science Ltd, Oxford, UK, pages 128-155.

Reschke da Cunha, C., Viotto, W.H. and Viotto, L.A. 2006. Use of low concentration retentates in reduced fat "Minas Frescal" cheese manufacture: effect on composition, proteolysis, viscoelastic properties and sensory acceptance. International Dairy Journal 16: 215-224.

Shamsia, S.M. and El-Ghannam, M.S. 2012. Manufacture of Labneh from cow's milk using ultrafiltration retentate with or without addition of permeate concentrate. Journal of Animal Production Advances 2: 166-173.

Sodini, I., Montella, J. and Tong, P.S. 2005. Physical properties of yogurt fortified with various commercial whey protein concentrates. Journal of the Science of Food and Agriculture 85: 853-859.

Tamime, A.Y. 2013. In: "Membrane Processing: Dairy and Beverage Applications", 1st Edition (ed. A.Y. Tamime), Development of membranes processes, Wiley-Blackwell, USA, pages 4-158.

Tamime, A.Y., Saarela, M., Sondergard, A.K., Mistry, V.V. and Shah, N.P. 2005. Production and maintenance of viability of probiotic microorganisms in dairy products. In: "Probiotic Dairy Products", 1st Edition (ed. A.T. Tamime), Blackwell Science Ltd, Oxford, UK, pages 39-72. 